\title{
Urban Violence: a challenge for geographers? Introduction to the special issue
}

\section{Jean-Bernard Racine, Lausanne}

The first signs of an upward trend in crime and violence became apparent in the 1970s and 1980s; the causes thereof were however seen to be peripheral in nature. The spotlight then in particular was on the role of schools and the effects of educational underachievement; these being seemingly logical explanations for the rise in crime and a reflection of the prevailing inequality of opportunities. The issue of violence in schools became a pivotal issue in political discourse during the 1990s, and many studies and reports on this topic appeared. Over the last twenty years all available indicators in France have pointed towards a continued rise in violence and incivility in cities. As a result, feelings of insecurity are becoming more widespread and are no longer confined to those areas usually identified as «insecure», such as the banlieues, the peripheral, housing projects situated on the outskirts of major French cities, long infamous for social deprivation and violence. Indeed, the seemingly unchallenged reign of delinquents in these areas - ever younger, ever more violent and ever more incorrigible - has become a national issue. Reports on violence dominate the media to such a degree that the French President, JACQues ChIRAC, began his speech on the occasion of the annual $14^{\text {th }}$ July celebrations in 2001 with the bold yet tragic assertion that «France is afraid!». He went on to refer to a «wave of violence sweeping» the country. However, although the number of trouble spots has virtually doubled in France over the last five years, it is important to note that many other neighbourhoods have remained remarkably unaffected - in particular due to the activities of local public authorities and voluntary associations. These spatial variations in the incidence of crime should make us wary about over-generalizations. Rather we should consider the multiplicity of causes of crime and its underlying complexity, and eschew the over-simplistic representations of its causes and the solutions that are proposed by politicians.

At first sight the levels of violence and crime appear to be diminishing, creating the illusion that a respite from the problems is possible. Published reports over the last ten years or so show that delinquency statistics in the USA seem to have levelled off and even to have declined in the major cities. Nevertheless, fear of violence - and particularly murderous violence remains so widespread in public opinion that a Gallup poll taken in 1998 showed that crime and violence remained the principal preoccupation among Americans. In Europe too, this preoccupation appears to be paramount. However, European statistical data does not seem to indicate any respite in crime levels, and, as we have seen above, the issue of crime and security is becoming a major political problem in most European countries. In addition, despite the similarities between their respective situations, we should take due note of the considerable suspicion with which Europeans view the American solutions to crime. This suspicion is based on two important beliefs. On the one hand, we should acknowledge that a considerable «cultural distance» separates these very different types of urban culture and society; on the other hand the normative conclusions advanced by the Americans are founded on analyses that are not sufficiently explained, as far as their methodologies and theoretical frameworks are concerned. But few Europeans maintain any pretence that they have managed any better than their transatlantic, or even trans-channel colleagues. Indeed, most agree that the problem of crime and delinquency is one that must be addressed and they would subscribe to the words that the British Prime Minister, Tony BLAIR, used in a 2001 address to local government officials: Government should be «tough on delinquency; tough on the causes of delinquency». Unfortunately being tough on crime may be treating symptoms, not causes, and these causes still need to be identified. But before we try to do this, we need to review the methods that have been used to identify and measure the exact extent of the phenomenon. For example, J.-B. RACINE (2002) dealt with this issue in a long review paper published by the IGU Urban Commission, and, together with VERONICA NOSEDA, a special report was prepared for the Municipality of Lausanne in the context of Agenda 21 (2004).

Although the recent rise in violence may lead some to conclude that the association of crime and violence with cities is a new phenomenon, a closer view of the literature shows that it is an opinion that cannot be upheld. Urban ecologists have long been interested in areas and groups involved in crime. But we need to cast our net wider than the twentieth century. Studies in archaeology and anthropology have shown the wide geographical spread of legends that narrate a human sacrifice at the foundation of virtually all the known cities of antiquity (GIRARD 1971; Racine 1993; Chalas 2000 ), so violence and cities are intimately intertwined or consubstantial. Throughout recorded history there 
is little doubt that violence was a characteristic of cities; fear of mob violence was a common concern of the élite in large cities. DicKENs's novels described what we would call «no-go areas» today, where the inhabitants led a life of crime in the so-called rookeries. Western urban society has never been homogeneous and equal (SHaw 1929). Indeed, the image of the city in our culture, constructed in previous centuries, has often been a dark one, that of a place of fear and danger, be this hygienic, physical or moral; cities, or certainly parts of them, are often seen to be inhabited by dangerous groups of people. It is an image constructed in opposition to the perspectives of modernity, and the good life that «modern" still implies today. As such, it carries the analysis of our understanding of acts of violence, not only in terms of inter-individual relationships, but also in terms of explanations introducing relationships that implicate human territoriality, social groups, and even social classes (REMY \& VoYÉ 1981). This is the very core of the debate concerning the injustice of unequal modernity and social dichotomy - whether that of «rich and poor» or of «in or out» - which provides a basis for the interpretation of violent acts. This is the theme of urban relegation, of social disqualification, or of social exclusion, the basis of socio-political analysis of urban questions. It is the galère described by DUBET in 1987.

Many people seem to forget these historic associations of inequality and cities, specifically of crime and cities. This is especially true among those investigators who prefer to posit crime as a conjunctural problem, essentially linking crime to some recent aspect of society. The most popular explanation is based on poor economic conditions, and especially on the succession of crises that have occurred between the beginning of the 1970s and the middle of the 1990s. The thesis of violence as a result of contemporary economic causes however, is difficult to sustain as such (SzLAKMANN 1992). Moreover, the latest statistics do not confirm the unemployment-crime linkage. It is very difficult under these circumstances - even for those amongst us most convinced by notions of the economic determination of behaviour and aware that instances of violence are the expression of the dissatisfactions embedded in the dominant social system of advanced liberal capitalism - to maintain that the growth in delinquency, at least in terms of aggregated statistics, is the result of unemployment.

Others have evoked a «societal evolution» explanation for violence and have suggested that the contemporary period is experiencing an entirely new phenomenon known as «urban violence». This is the phenomenon that Commissioner BUI-Trong (2000) described as

«a violence specific to young people acting in gangs and attacking property - applying graffiti, shoplifting, raids, throwing stones through the windows of schools and at public transport, throwing Molotov cocktails at vehicles, shops and residential buildings in their neighbourhoods - and also attacking persons, such as through inter-gang and inter-ethnic confrontation, protection rackets, stealing from school children and middleclass youngsters, punitive attacks on teachers, bus drivers, shop security agents, police, and displaying menacing and/or violent confrontation».

Finally, there is a group of non-exclusive factors identified by PAUL WILEs (1999) that provide additional distinctive characteristics to certain problem neighbourhoods. Among the most important of these factors are: the neighbourhood's multiculturalism, which renders agreement on collective norms more difficult; the economic and social marginalization of some families; the dilapidation of the extensive pool of public housing due to the non-payment of rents and the indebted state of the families; the exclusion of the inhabitants of recently urbanized zones from any participation in civic and political processes; the seemingly pervasive educational under-achievement; and the pernicious influence of drug-trafficking.

We must also acknowledge the role played by the media in our consciousness of these problems. Incessantly, they broadcast images of the dangerous «otherness» of these areas, which indubitably contributes to the pervasive atmosphere of "moral panic» and the fear of general insecurity, accentuating the social and ethnic fractures that split the city. In addition, and perhaps worst of all, there is the feeling of what can be called spatial despair, the inability of residents to exercise control over the area in which they live, the lack of recognition (HONNETH 2000; LAGRANGE 2000), as well as the persuasive self-denigration among the residents (NOSEDA \& RACINE 2004). These feelings, combined with the difficulties of living in «sink neighbourhoods», frequently result in the departure of those families that can afford to move. This reduces the number of people who may provide role models for others and especially for the children. What is left is the indifference of the majority who remain and the violence of some: this is not simply random or anarchic, but is an expression of personal or collective despair. It is a mechanism that not only affects individuals, but also affects neighbourhoods, or even an urban community in its entirety (RACINE 2003).

These varied suggestions represent some of the more important types of reasons that have been proposed for the increase in crime and violence. In themselves they demonstrate that the problem is associated with multiple reasons. However, it may be easy to suggest causes. What is more difficult is to find explanations that can be justified by the evidence (Mucchielli 2001). 
The arguments developed in the following papers do not necessarily follow the path taken by institutional specialists in crime and violence; they certainly do not follow the approaches often favoured by the forces of law and order. Indeed, we believe that the latter's enterprises - whether in the measurement of the phenomenon, or in its interpretation - should be subject to considerable circumspection. We must ask the question: does the inherent risk of the different approaches proposed tend to distance us from any comprehensive appreciation of the relevant issues, and may it even impede us in producing some new understanding of crime, and perhaps its monitoring, that is capable of engaging the objectives of both social justice and democracy? These are some of the issues developed by Veronica Noseda, PhD student at the University of Lausanne. Retracing in a reflexive and critical fashion the origins of categories of «incivilities», «exclusion» and «urban violence», she argues in favour of a new understanding of the political role that geographers could play in the public debate where the concept of territory emerges as a political actor in and of itself.

The second paper deals with the most serious case of urban violence, Johannesburg, the so called city of crime, about which Philippe Guillaume wrote in his French Ph.D. Between reality and what can often be considered as pretext, serving the interests of those who pretend to be the victims, the author tries to find ways to overcome intolerance, racism, and misunderstanding. Building institutions, rethinking social relations, closing the gap, reinventing democracy: these are some of the most aspiring goals being followed in South Africa, the achievement of these however being severely hindered by violence itself. This paper is an invitation to study the influence of violence in society, to determine its role in common discourse and the consequences thereof on social dynamics.

The third paper is presented by Henri Motcho, University of Niamey, and shows how the rapid growth of the city (10\% of annual growth since 1970$)$ aggravates various problem areas, such as housing, health and especially security. Increasing insecurity is the result of two main factors which are closely linked: increasing poverty and lack of education and support for the younger generation. Juvenile delinquency is becoming more and more prevalent as a rising number of children take to living in the streets. The associated rise in petty thefts or worse may be seen as indicators of organized crime. The authorities are not in a situation to cope with the growing insecurity. Therefore many housing developers try to involve traditional power structures in their programmes from as early on as possible in order to help the police forces, who are supported by private (partially ambiguous) militias.
This underlines the importance of local and traditional chiefs in the administration of the city of Niamey.

In a totally different context, Professor David Herbert from the University of Wales at Swansee, already well known for his work on urban violence (HERBERT 1976, 1977), confirms the generally accepted fact that levels of violence are increasing but reminds the reader that there are significant regional differences. If recent studies review these assumptions and examine the problems associated with monitoring the incidence of violent crime, the author shows that there are new dimensions to urban violence, including the rise in drug trafficking, in organized crime and in use of firearms. Certainly, cities offer specific situations in which violent crime is more likely to occur. There are geographies of violent crime that highlight not only the differences between cities but also define the local concentrations within individual cities. In conclusion, DAvid HERBERT shows how society seeks to control violent crime, principally through its criminal justice systems but also by involving community action and local initiatives.

The Canadian geographer, WAYNe Davies, Calgary University, proposes that if traditional studies by geographers of crime areas within cities focus on spatial variations in crime incidence, as well as social deprivation and social disorganization in these areas, and if these social contexts and behavioural features are often highly correlated with crime areas, then analytical studies of crime areas need to be extended to deal with the feelings and attitudes of people in these areas. Ten separate dimensions of the affective domain are hypothesized, each of which describes different feelings and attitudes that characterize crime areas. Confirmation of these dimensions must wait for empirical testing but they point the way to the systematic development of a psycho-geography of crime areas in which the dimensions can be linked to different theories of criminal behaviour. Indeed, this proposal is definitely of value and promises to open new ways to understanding and acting on violent crime.

Changing the scale of scope, STÉPHANE RosièrE's paper introduces the concept of «Ethnic Cleansing» (EC) and offers a typology of this phenomenon as an expression to be understood as geographical in nature and including indicators easily differentiated from genocide. His typology draws on two main factors: level of integration of the study area in the global system and population density. Thus, areas undergoing radical transformation (by various violent means) fall into the category of predation EC, used in particular to explain situations in which ethnical groups fight each other in order to control resources which are vital for their survival. Social control EC is conceived as a transitional 
category, tending in the direction of the sociological concepts of genocide and politicide. We are encouraged to critically examine whether the most recent forms of violence are really the least suitable forms of action for inducing improvement, at least in the eyes of a geographer.

Thus, it becomes apparent from this special issue that territorial actions which favour the local level are of primary importance for the prevention of violence and delinquency. These preventative actions should be used in the front line as instruments of mediation, complimenting the activities of the police force and developed in close collaboration with them. In addition, every individual is encouraged to become active as well, be this in setting up local contacts for security purposes or tackling delinquency - whether formalized or not. For the successful engagement of all activists, it is necessary that all parties work together, consciously interlinking lived, perceived, and represented spaces, in order to identify or discover new pertinent scales of intervention, both at intercommunal and intracommunal levels. This interconnectivity of action would certainly be a major undertaking; it would certainly be more ambitious than simply trying to add a new single approach for the problems posed by violence based on some recently discovered factor. Nevertheless, it promises to be the most appropriate factor of regulatory action in the future. The interconnection of local actors may be more effective than attempts to monitor trends or solutions, as this would contribute towards a better understanding, and perhaps even the reduction of severe problems of delinquency and crime in so-called problem neighbourhoods and in other areas where violence takes place.

\section{References}

Bui-Trong, L. (2000): Violences urbaines: des vérités qui dérangent. - Paris: Bayard.

Chalas, Y. (2000): L'invention de la ville. - Paris: Anthropos, coll. Villes.

DUBEt, F. (1987): La galère: jeunes en survie. - Paris: Fayard.

GiRARD, R. (1971): La violence et le sacré. - Paris: Grasset.

HERBERT, D.T. (1976): The study of delinquincy areas: a social geographical approach. - In: Transactions, Institute of British Geographers, New Series 1, 4: 472-492. Herbert, D.T. (1977): Crime, delinquency and the urban environment. - In: Progress in Human Geography 1,2:208-239.
Honneth, A. (2000): La lutte pour la reconnaissance. Paris: Edition du Cerf.

LAgrange, H. (2000): Reconnaissance, délinquance et violences collectives. - In: Esprit, Oct.: 131-151.

Mucchielli, L. (2001): Violences et insécurité: Fantasmes et réalités dans le débat français. - Paris: La Découverte.

Noseda, V. \& J.-B. Racine (2004): Violences urbaines. Une exploration au-delà des interprétations reçues. Le regard du géographe dans une approche transdisciplinaire. = Agenda 21, Lausanne: Institut de Géographie et Ville de Lausanne.

RACINE, J.-B. (1993): La ville entre Dieu et les hommes. - Genève: Presses bibliques universitaires.

RACINE, J.-B. (2002): Explaining, regularing or monitoring violence in the cities of tomorrow: Appraisals Draws from the French and Swiss Experiences. In: Davies, W.K.D. \& I.J. Townshend (éds.): Monitoring cities: International Perspectives. - Calgary: International Geographical Union, Urban Commission: 557-598.

RACINE, J.-B. (2003): Durabilité sociale et pathologies urbaines: le problème de la violence. - In: Da CunHA, A. \& J. Ruegg (éds.): Développement durable et aménagement du territoire. - Lausanne: Presses polytechniques et universitaires romandes: 101-126.

Remy, J. \& L. Voyé (1981): Ville, ordre et violence, formes spatiales et transaction sociale. - Paris: Presses Universitaires de France: 112-113.

SHaw, C.R. (1929): Delinquency and Crime areas in Chicago. - Chicago: University of Chicago.

Szlakmann, C. (1992): La violence urbaine: A contrecourant des idées reçues. - Paris: Laffont.

WILES, P. (1999): Troubled neighbourhoods. - In: BRUinsma, G. \& C.D. VAN der ViJver (eds): Public Safety in Europe. - Enschede: Twente University.

Prof. Dr. Jean-Bernard Racine, Institut de Géographie, Université de Lausanne, BFSH II, CH-1015 Lausanne/ Dorigny.

e-mail: Jean-Bernard.Racine@igul.unil.ch 